\title{
Ameliorative potential of Tephrosia purpurea extract against arsenic induced toxicity in wistar rats
}

\author{
Ravuri Halley Gora, Sushma Lalita Baxla, Priscilla Kerketta ${ }^{1}$, Reetu Toppo, Naveen Kumar and Birendra Kumar Roy \\ Ranchi Veterinary College, Birsa Agricultural University, Ranchi - 834006, J harkhand, India.; \\ 1. Indian Veterinary Research Institute (IVRI), Izatnagar, Bareilly - 243122, U.P. India \\ Corresponding author: Ravuri Halley Gora, email: halleygora@gmail.com \\ Received: 08-01-2013, Revised: 31-01-2013, Accepted: 02-02-2013, Published online: 16-05-2013 \\ How to cite this article: \\ Gora RH, Baxla SL, Kerketta P, Toppo R, Kumar N and Roy BK (2013) Ameliorative potential of Tephrosia purpurea against \\ arsenic induced toxicity in wistar rats, Vet World 6(8): 493-496, doi: 10.5455/vetworld.2013.493-496
}

\begin{abstract}
Aim: The present investigation has been conducted to evaluate the protective activity of Tephrosia purpurea extract (TPE) against arsenic induced toxicity.

Materials and Methods: For this study, twenty four wistar albino rats were taken. Control group, group - I rats were given sodium arsenite @ $10 \mathrm{mg} / \mathrm{kg}$ and group - II rats were treated with TPE @ $500 \mathrm{mg} / \mathrm{kg}$ along with sodium arsenite @ $10 \mathrm{mg} / \mathrm{kg}$ (daily oral for 28 days). On $29^{\text {th }}$ day animals were slaughtered and various parameters were determined. Serum biomarkers, haematological parameter analysis and histomorphological examination are carried out with estimation of arsenic concentration in tissues.

Results: Oral administration of sodium arsenite @ $10 \mathrm{mg} / \mathrm{kg}$ for 28 days resulted in a significant decrease in $\mathrm{Hb} \%$, TEC and TLC, significant increase of serum glucose, cholesterol, calcium and significant increase in arsenic accumulation in tissues. Histopathological results of intestine revealed haemorrhagic enteritis along with loss of villi. Treatment with Tephrosia purpurea@ $0500 \mathrm{mg} / \mathrm{kg}$ significantly decreased the elevated glucose, LDH levels, along with significant increase haematological levels towards normal. There was reduced haemorrhagic enteritis and presence of intact villi, as compared to arsenic treated group. But there was no significant difference in serum calcium, serum cholesterol and arsenic concentration in tissues, when compared with arsenic treated group.
\end{abstract}

Conclusion: The study conclude that supplementation of TPE $(500 \mathrm{mg} / \mathrm{kg})$ daily oral for 28 days has shown protection against arsenic induced toxicity by its protective effect.

Keywords: arsenic, haematology, rats, serum bio-markers, Tephrosia purpurea, toxicity

\section{Introduction}

Arsenic is a toxic metalloid and is a common environmental pollutant, virtually present in rocks, soil and water and is second most important pollutant next to lead [1]. Exposure to arsenic is known to induce a wide range of toxic effects on brain [2], induces fibrosis of liver [3] and oxidative stress in the body. Arsenic mainly effects liver and kidney [4] and causes damage to them. Heavy metals induce over production of reactive oxygen species (ROS) and consequently enhance lipid peroxidation, decrease the saturated fatty acids and increase the unsaturated fatty acid contents of membranes. Herbal plants with flavonoids and polyphenols are potent inhibitors of oxidative stress [5]. Tephrosia purpurea is commonly known as "Sharphunka" in Hindi and its leaves were used as constituent in liver tonics [6], have a potent nephroprotective activity [7] and antioxidant property [8].

To best of our knowledge there was no scientific report regarding the efficacy of Tephrosia purpurea against arsenic induced toxicity. We have conducted this experiment to study the effect of Tephrosia purpurea extract against arsenic induced toxicity.

This article is an open access article licensed under the terms of the Creative Commons Attribution License (http://creativecommons. org/licenses/by/2.0) which permits unrestricted use, distribution and reproduction in any medium, provided the work is properly cited.

\section{Materials and Methods}

Experimental animals: Twenty four wistar albino rats were taken and randomly divided in to three groups $(n=8)$. They were housed in propylene cages under standard laboratory conditions with standard food and water ad-libitum. For this study, control group in which healthy rats were included and given standard diet and deionised water, group-I rats were given sodium arsenite @ $10 \mathrm{mg} / \mathrm{kg}$ daily oral for 28 days and group II rats were treated with Tephrosia purpurea@ 500 $\mathrm{mg} / \mathrm{kg}$ along with sodium arsenite@10 mg/kg daily oral for 28 days.

Ethical approval: The protocol of the experiment was approved by the Institutional Animal Ethical Committee according to guidelines given by Committee for the Purpose of Control and Supervision of Experiments on Animals (CPCSEA).

Chemicals: Sodium arsenite (HiMedia Laboratories Pvt. Ltd., Mumbai, India) was used as source of arsenic in this study. Sodium arsenite powder was dissolved in distilled water and given orally to individual animals @ $10 \mathrm{mg} / \mathrm{kg}$ [9].

Plant extract: The hydro-alcoholic extract was used along with gum acacia for oral administration@ 500 $\mathrm{mg} / \mathrm{kg}$ [10]. 
Table-1. Effect of arsenic alone and with TPE on haematological and serum bio-markers parameters $($ Mean \pm SEM) $(n=8)$.

\begin{tabular}{|c|c|c|c|}
\hline Parameters & Control & Group - I & Group - II \\
\hline $\operatorname{TEC}\left(10^{6} / \mu \mathrm{l}\right)$ & $8.88 \pm 0.32$ & $7.04 \pm 0.30^{* *}$ & $8.07 \pm 0.31^{A *}$ \\
\hline $\operatorname{TLC}\left(10^{3} / \mu \mathrm{l}\right)$ & $9.01 \pm 0.28$ & $6.33 \pm 0.19^{* *}$ & $7.66 \pm 0.26^{A_{\star *}}$ \\
\hline $\mathrm{Hb}(\mathrm{mg} \%)$ & $13.96 \pm 0.16$ & $12.40 \pm 0.35^{\star *}$ & $13.38 \pm 0.23^{A *}$ \\
\hline Serum glucose (mg/dl) & $65.23 \pm 6.75$ & $86.30 \pm 4.68^{*}$ & $72.72 \pm 3.29^{A_{*}}$ \\
\hline Serum cholesterol (mg/dl) & $135.05 \pm 2.49$ & $201.32 \pm 16.31^{*}$ & $160.65 \pm 13.02^{\mathrm{NS}}$ \\
\hline Serum calcium (mg/dl) & $6.91 \pm 0.60$ & $11.71 \pm 1.20^{* *}$ & $8.54 \pm 1.22^{\mathrm{NS}}$ \\
\hline Serum LDH (IU/L) & $331.94 \pm 42.22$ & $574.78 \pm 28.32^{\star \star}$ & $451.29 \pm 45.86^{A_{*}}$ \\
\hline
\end{tabular}

$* * P<0.01 ; * P<0.05$; statistically significant when compared to control group.

${ }^{A} * P<0.05 ;{ }^{A} * * P<0.01$; statistically significant when compared to group - 1 .

NS: statistically non-significant when compared with group - I.

Sample collection: At end of the experiment, all animals were sacrified on day 29, serum, blood and tissues samples were collected and following parameters were estimated.

Haematological parameters: Haematological parameters viz., $\mathrm{Hb} \%$ (haemoglobin \%), Total erythrocyte count (TEC) and Total leucocyte count (TLC) were estimated according to [11].

Biochemical estimation: Activities of glucose, LDH, Serum Cholesterol and Calcium in serum were analysed using Erba Semi-autoanalyzer (ERBA Diagnostics Mannheim GmbH, Mallaustr, 69-73, D68219, Mannheim/Germany) by Erba-biochemkits.

Histopathology: Histopathology of Buffered formalin fixed intestine samples were routinely processed, cut at $5 \mu \mathrm{m}$ and stained with $\mathrm{H} \& \mathrm{E}$ stain [12].

Arsenic concentration: Arsenic concentration was quantitatively analysed on day 29 in different tissues (heart, lungs, bone and muscle) with the help of AAS. Total arsenic was quantified by digestion, using tri-acid mixture of nitric acid, perchloric acid and sulphuric acid (10:4:1) following the method of [13]. The digested samples were diluted with deionized Millipore water, passed through Whatman filter paper No. 4 and made the volume to $10 \mathrm{ml}$. Concentrated hydrochloric acid $(5 \mathrm{ml})$ was added to it and shaken well. Then $0.3 \mathrm{ml}$ of potassium iodide (5\%) and ascorbic acid (5\%) mixture was added and kept the aliquot for $45 \mathrm{~min}$ for transformation of arsenate to arsenite. The final volume was made up to $25 \mathrm{ml}$ with Millipore water and arsenic concentration read on Varian AA240 model AAS Atomic Absorption Spectrometer (AAS) equipped with vapour generation accessories. The operating parameters were: lamp, arsenic hollow cathode lamp; wavelength, $193.7 \mathrm{~nm}$; slit width, $0.5 \mathrm{~nm}$; lamp current, $10.0 \mathrm{~mA}$; vapor type, air/acetylene; air flow, $10.00 \mathrm{~L} / \mathrm{min}$; inert gas for hydride generation, Argon. Reducing agent (Aqueous solution of $0.6 \%$ sodium borohydride was prepared in $0.5 \% \mathrm{w} / \mathrm{v}$ sodium hydroxide) and $40 \% \mathrm{HCl}$ were prepared freshly before use. Working standard solutions were prepared by dilution of stock (1000 ì $\mathrm{g} / \mathrm{ml}$ ) and intermediate (10 ì $\mathrm{g} / \mathrm{ml})$ standards. The working standards were as follows: 5, 10, 20 and 40 i $\mathrm{g} / \mathrm{L}$ and prepared it by same procedure as test sample.
Statistical analysis: Quantitative data were analyzed using the ANOVA. Value $P \leq 0.05$ and $P \leq 0.01$ were considered significant at $5 \%$ and $1 \%$, level respectively.

\section{Results and Discussion}

Exposure to arsenic for a short period of time causes metabolic disturbances and is considered as major public issue [14]. Chronic exposure to arsenic causes increase in blood pressure, diabetes, cardiovascular diseases and cancer [15]. The present study shows the effect of arsenic on the body by considering various parameters like haematological, serum bio-marker levels and estimation of arsenic concentration in the body. In this present study there was significant decrease in the values of $\mathrm{Hb} \%$, TLC and TEC in Group-I as compared to control group. In Group - II there was significant increase in the altered levels as compared to Group-I and given in Table-1. The decrease in $\mathrm{Hb} \%$ in sodium arsenite exposed group might be due to reduced haemoglobin synthesis. About $85 \%$ of haeme-biosynthesis takes place in bone marrow and $15 \%$ in liver. Arsenic binds with the sulphydryl group containing enzymes which are required for haeme synthesis, causing inhibition of these enzymes.

The results obtained in this study are in agreement with the results obtained by $[16,17]$. There was decreased TEC in rats treated with sodium arsenite [18]. This reduction in the total erythrocyte count may be due to inhibition of erythropoiesis by arsenic. In present study there was significant decrease in TLC in sodium arsenite treated group, this might be due to due to its suppression of bone marrow activity and causing reduced granulopoietic action which was in accordance with [19]. The increase in $\mathrm{Hb} \%$ in group II may be due to the erythrocyte membrane integrity enhancing effect on red blood cells [20]. The increase in the TEC might be due to selective effect of Tephrosia purpurea on erythroid compartment [21]. There was an increased level in serum glucose (Table-1), in group-I as compared to control group and significant decrease in group-II as compared to group-I. similar results were reported by [22-25]. Arsenic causes pancreatic â-cell apoptosis [26] and suppress insulin secretion causing increased glucose in blood. This might be the cause of increased glucose in the body. According to [27], exposure to high levels of arsenic causes diabetes and increased levels of glucose in blood. There was also 
Table-2. Effect of arsenic alone and with TPE on arsenic concentration (ppm) in organs. (Mean \pm SEM) $(n=8)$.

\begin{tabular}{llll}
\hline Tissues & Control & Group - I & Group - II \\
\hline Heart & $0.26 \pm 0.11$ & $6.04 \pm 0.51^{* *}$ & $5.67 \pm 0.32^{\mathrm{NS}}$ \\
Lungs & $0.17 \pm 0.07$ & $11.01 \pm 1.10^{* *}$ & $8.74 \pm 1.22^{\mathrm{NS}}$ \\
Muscles & $0.21 \pm 0.02$ & $6.47 \pm 0.31^{* *}$ & $6.29 \pm 0.17^{\mathrm{NS}}$ \\
Bone & $0.06 \pm 0.01$ & $6.20 \pm 0.39^{* *}$ & $6.06 \pm 0.50^{\mathrm{NS}}$ \\
\hline
\end{tabular}

$* * P<0.01$; statistically significant when compared to control group. NS; statistically non-significant when compared to group - I.

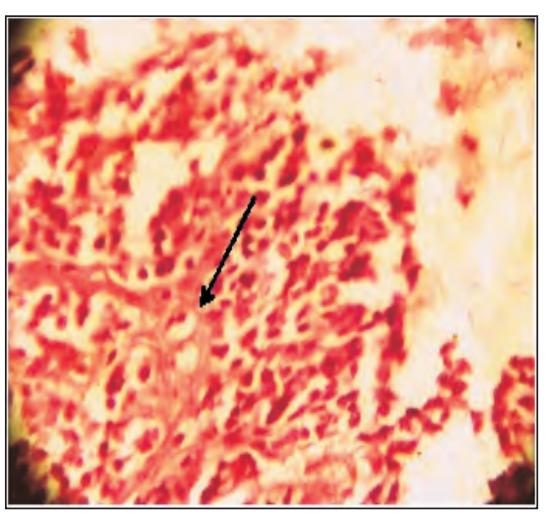

Figure-1. Photograph showing haemorrhagic changes, necrosis and loss of villi in intestine of rats of group-I (H\&E X 400)

significant increase in serum calcium, LDH and cholesterol levels (Table-1) in group-I as compared to control group and significant decrease in LDH in group -II as compared to group-I. Similarly increased serum calcium in arsenic exposed rats was also reported by [22]. Increased levels of LDH were also reported by $[28,29]$. The increase in LDH levels might be due to the damage to liver, heart and kidney due to arsenic. The decrease in serum glucose in group-II might be due to the hypoglycaemic activity of Tephrosia purpurea [30]. Table- 2 shows the arsenic concentration in heart, lungs, bone and muscles in different groups. At the end of the experiment on $28^{\text {th }}$ day, there was significant increase in the arsenic concentration in tissues of Group - I and II as compared to control group. Arsenic concentration was high in lungs as compared to other tissues. Concentration of arsenic in tissues of rats treated with sodium arsenite for 30 days was estimated by [31] using hydride generation atomic absorption spectrophotometer and reported that there was significant increase in arsenic content in lungs, liver and kidney of arsenic treated group as compared with control and reported that muscles, bones, lungs and kidneys contain highest concentrations of arsenic and distribution of trivalent arsenic is 2-2.5 times more than pentavalent arsenic in these organs. Histopathological examination revealed severe necrosis, loss of villi and haemorrhagic lesions in arsenic treated group (Figure- 1). According to [27] there was necrosis of intestinal mucosa and haemorrhagic enteritis in arsenic exposed population. There was reduced haemorrhagic enteritis and intact villi in intestine of group-II rats (Figure-2). This might be due to antiiflammatory and protective effect of Tephrosia purpurea. Study proves that exposure to arsenic for 28 days causes toxicity in the body. It was confirmed by the results shown in this study. The reduced haematological parameters indicate

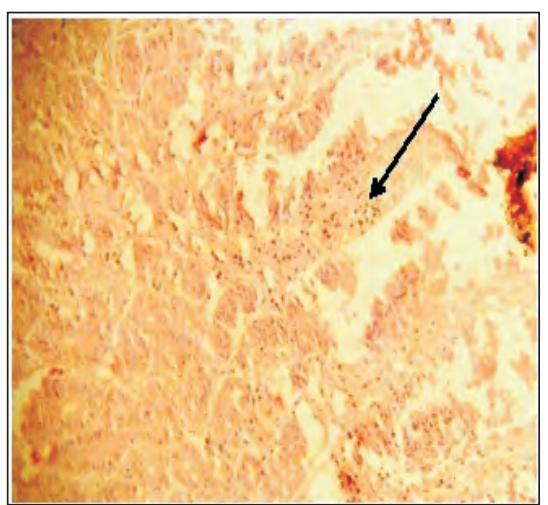

Figure-2. Photograph showing intact villi and reduced haemorrghage in intestine of rats of group-II (H\&E X 400)

that arsenic has detrimental effects on bone marrow. Treatment Tephrosia purpurea @ 500 mg/kg showed mild protective effect against arsenic toxicity.

\section{Conclusion}

It is proved that supplementation of Tephrosia purpurea extract ( $500 \mathrm{mg} / \mathrm{kg} \mathrm{PO}$ ) daily for 28 days has given protection against arsenic induced toxicity, which was confirmed by the results shown in this study.

\section{Authors' contribution}

All authors contributed equally. All authors read and approved the final manuscript.

\section{Acknowledgements}

Authors are thankful to The Vice-Chancellor for providing the fund for this study and Dean, Ranchi Veterinary College for supporting the research.

\section{Competing interests}

Authors declare that they have no competing interest.

\section{References}

1. Buck, W. B., Osweiler, G. D. and Van Gelder, G. A. (1976) Clinical and Diagnostic Veterinary Toxicology, $2^{\text {nd }}$ Edn. Kendall-Hunt Publishing Co., Dubuque, IOWA, 281-288.

2. Rao, M.V. and Avani, G. (2004) Arsenic-induced free radical toxicity in brain of mice. Ind. J. Exp. Biol., 42: 495508.

3. Mandal, A.K., Das, S., Basu, M.K., Chakrabarti, R.N. and Das. N. (2007) Hepatoprotective activity of liposomal flavonoid against arsenite-induced liver fibrosis. $J$. Pharmacol.Exp. Ther., 320(3): 994-1001.

4. Roy, M., Pandey, P. K., Roy, S. and Chauhan, H. V. S. (2008) Arsenic induced haematobiochemical and histopathological alterations and its level in certain biological samples. Toxicol. Int., 25(1):57-62.

5. Flora, S. J., Chouhan, S., Kannan, G. M. and Swarnkar, H. (2008) Combined administration of taurine and mono isoamyl DMSA protects arsenic induced oxidative injury in 
rats. Oxid. Med. Cell. Longev, 1:39-45.

6. Samy, R. P., Pushparaj, P. N. and Gopalakrishnakone, P. (2008) A compilation of bioactive compounds from Ayurveda. Bioinform., 3(3): 100-110.

7. Khan, N., Sharma, S., Alam, A., Saleem, M. and Sultana, S. (2001) Tephrosia purpurea ameliorates N-diethylnitrosamine and Potassium bromate mediated renal oxidative stress and toxicity in rats. Pharmacol. Toxicol., 88: 294-299.

8. Jain, A., Lodhi, S. and Singhai, A. K. (2009) Simultaneous estimation of quercetin and rutin in Tephrosia purpurea pers by high-performance thin-layer chromatography. Asian. $J$. Trad. Med., 4(3): 104-109.

9. Brown, J. L. and Kitchin, K. T. (1996) Arsenite, but not cadmium, induces ornithine decarboxylase and heme oxygenase activity in rat liver: relevance to arsenic carcinogenesis. Cancer Lett, 98: 227-31.

10. Khatri, A., Garg, A., Agrawal, S. S. (2009): Evaluation of hepatoprotective activity of aerial parts of Tephrosia purpurea and stem bark of Tecomella undulate. J. Ethnopharm. 122: $1-5$.

11. Schalm O. W., Jain, N. C and Carroll, E. J. (1975) Veterinary Haematolgy, $4^{\text {th }}$ ed. Lea and Febiger, Philadelphia. Pp: 15-81.

12. Culling, C. F. A. (1974) Hand book of Histopathological and Histochemical techniques, $3^{\text {rd }}$ ed, Butterworth \& Co. ltd, London: 88 Kingsway, WC2B 6AB.

13. Datta, B. K., Mishra, A., Singh, A., Sar, T. K., Sarkar, S., Bhatacharya, A., Chakraborty, A. K. and Mandal, T. K. (2010) Chronic arsenicosis in cattle with special reference to its metabolism in arsenic endemic village of Nadia district West Bengal India. Sci Total Environ, 409:284-288.

14. Roy, D., Das, T. K. and Vaswani, S. (2013) Arsenic: it's extent of pollution and toxicosis: An animal perspective. Vet World, 6(1): 53-58.

15. Rahman, M. M., Ng, J. C. and Naidu, R. (2009) Chronic exposure of arsenic via drinking water and its adverse health impacts on humans. Environ Geochem Health, 1: 189-200.

16. Rana, T., Sarkar, S., Mandal, T. K. and Batabyal, S. (2008) Haematobiochemical profiles of affected cattle at arsenic prone zone in Haringhata block of Nadia District of West Bengal in India. The Internet. J. Haematol., 4(2): 1642-1657.

17. Flora, S. J. S., Bhadauria, S., Pant, S. C. and Dhaked, R. K. (2005) Arsenic induced blood and brain oxidative stress and its response to some thiol chelators in rats. Lif. Sci., 77(18): 2324-2337.

18. Tandon, N., Roy, M. and Roy, S. (2012) Ameliorative potential of Psidium guajava on haematobiochemical alterations in arsenic-exposed wistar rats. Toxicol Int, 19:
121-124

19. Sajan, R., Singh, S. P., Varma, R. and Choudary, G. K. (2009) Ameliorative efficacy of Pipera longum in arsenic induced toxicity in cockerel. J. Vet. Pharmacol. Toxicol., 8(1-2): 41-43.

20. Gokhale, A. B. and Saraf, M. N. (2000) Tephrosia purpurea: A review of contemporary literature and medicinal properties. Indian drugs. Ind. J. Pharm. Sci., 37: 228.

21. Taraphdar, A. K., Shaw, B. P., Bhattacharya, R. K. and Mukherjee, P. K. (2002) Role of sharpunka (T.purpurea) in haemopoietic injury. Antiseptic., 99(8): 302-304.

22. Roy, M. and Roy, S. (2011): Ameliorative potential of Psidium guajava in induced arsenic toxicity in wistar rats. Vet World. 4(2): 82-83.

23. Nashwah, I. Z., Manal, E. A. El.h., Sabar, K. D. and Mohammed, A. S. (2011) Impacts of paracetamol, malathion and arsenic or their combinations on liver and pancreas of albino rats. Aust. J. Bas. App. Sci. 5(10): 473-481.

24. Karim, M. R., Haque, A., Islam, K., Ali, N., Salam, K. A., Saud, Z. A., Hossain, E., Fajol, A., Akhand, A. A., Himeno, S and Hossain, K. (2010) Protective effects of the dietary supplementation of turmeric (curcuma longa L.) on sodium arsenite-induced biochemical perturbation in mice. Bangl. Med. Res. Counc. Bull. 36:82-88.

25. Patel, H. V. and Kalia, K. (2010) Sub-chronic arsenic exposure aggravates nephrotoxicity in experimental diabetic rats. Ind. J. Exp. Biol., 48: 762-768.

26. Lu, T.H., Su, C.C., Chen, Y.W., Yang, C.Y., Wu, C.C., Hung, D.Z., Chen, C.H., Cheng, P.W., Liu, S.H. and Huang, C.F. (2011) Arsenic induces pancreatic â-cell apoptosis via the oxidative stress-regulated mitochondria dependent and endoplasmic reticulum stress triggered signalling pathway. Toxicol. Lett. 201(1): 15-26.

27. Pimpar, B. D. and Bhave, A. (2010) Arsenicosis: review of recent advances. JAPI. 58:617-629.

28. Nassr-Allah, H and Abdel-Hameid (2009) A protective effect of calcium carbonate against arsenic toxicity of the nile cat fish Clarias gariepinus. Turk. J. Fish. Aqua. Sci. 9: 191-200.

29. Saad, S. Y., Alkharfy, K. M. and Arafah, M. M. (2006) Cardiotoxic effects of arsenic trioxide/imatinib mesilate combination in rats. J. Pharm. Pharmacol. 58(4): 567-573.

30. Joshi, N. C., Murugananthan, G., Thabah, P. and Nandakumar, K. (2008) Hypoglycemic and antidiabetic activity of T. purpurea (Linn.) root extracts. Pharmacol. online. 3: 926-933.

31. Islam, M. S., Awal, M. A., Mostofa, M., Gosh, A. and Khair, A. (2009) Effect of spinach against arsenic toxicity in rats. Bangl.J. Vet. Med., 7(2): 358-363.

$* * * * * * * *$ 